\title{
2000 年国際パルプ漂白会議に参加して
}

\author{
日本製紙株式会社 技術研究所パルプ研究室 宮 西 孝 則
}

\section{Reports of 2000 International Pulp Bleaching Conference}

\author{
Takanori Miyanishi \\ Pulp and Paper Research Laboratory of Nippon Paper Industries Co., Ltd.
}

\begin{abstract}
2000 International Pulp Bleaching Conference took place in Halifax. Nova Scotia, Canada, during June 27-30 in 2000. Technical papers included 34 papers in the oral presentations and 40 papers in the poster presentations. They dealt with the topics of pulping, washing, oxygen delignification, ECF bleaching and system closure. Mill experiences with the medium consistency ozone bleaching were reviewed. Ozone has proven to be a practical and powerful bleaching reagent. When incorporated into an ECF sequence, ozone improved bleaching economy while significantly reducing environmental loading. Despite some ongoing concerns on NPE (non-process element) it is clear that ozone bleaching has found a firm place in bleaching.
\end{abstract}

Keywords : bleaching. ECF, mill closure, NPE, ozone

分類： $K_{1}$ パルプの漂白一般， $Z_{\text {; 外郭団体会議 }}$

\section{1.はじめに}

2000 年 6 月 27 日から 30 日までの 4 日間にカナタ のハリファックスで開催された国際バルブ漂白会議 (2000 International Pulp Bleaching Conference) に参 加する機会を得たので概要を報告する。

ハリファックスはカナタ東端、大西洋に望むノバス コシア州の州都で、天然の良港である。17 世紀にフ ランス人の探検家，移民たちによって発見，開拓され た。多数のフランス系入植者が住んでいたが、 ヨーロ ッパにおける列強の勢力争いの結果として, 1713 年に ユトレヒト条約が成立し，イギリスに割諒された。そ の後も，而国の間で度々争いが起こり，フランス系と の戦いに決着をつけるため,イギリス軍は要塞を構筞 した。会議の会場に近いハリファックス・シタデル・ パークは，この要塞の跡地を公園にしたもので，ハリ ファクスは五稜郭のある函館と姉妹都市になっている。 1912 年に大西洋でタイタニック号が氷山に街突して 沈没した時, 救助船を出して遗体を收容し墓地に埋葬 したのがハリファックスで, 最近の映画タイタニック のヒットにより観光客も增加している。ノハスコシア 州には 11 の大学があり, 人口当たりの大学数は北米
でもっとも多い。ハリファックスは 6 校の大学を有し， 赤毛のアンの著者であるモンコメリー女史の通ったタ ルハウジー大学もある文化の香る街である。

オープニングセッションの講演は, 米国の情報コン サルタント会社による情報化社会における紙の未来予 測であった。米国では高学歴化が進み (sophisticated), まもなく大学進学率が $50 \%$ に達する。高学歴で高収 入の人々は (practical discretion), パソコンを購入し インターネットを活用するが (targeted and interactive communication), インターネットだけでなく複 数の情報源を求めて書籍、新聞も定期的に読む傾向か あり (information powered), インターネットの検索 には紙のカタロクを利用するようになる。その結果, ますます紙の需要は增加するとの明るい見通しを立て ていた。

研究発表は, 口頭発表が 10 のセッションで 34 件, ポスターが 13 のセッションで 40 件, 合計 73 件の報 告があった。下記に口頭発表のプログラムを示す。

$$
\begin{array}{ll}
\text { セッション } 1: \text { 蒸解 } & 4 \text { 件 } \\
\text { セッション } 2: \text { 蒸解と洗浄 } & 4 \text { 件 } \\
\text { セッション } 3: \text { 酸素脱リタニン (その 1) } & 3 \text { 件 } \\
\text { セッション } 4: \text { 酸素脱リタニン (その 2) } & 3 \text { 件 }
\end{array}
$$


セッション 5 : ECF 漂白

セッション $6:$ その他の漂白薬品

セッション $7:$ パルプの品質

4 件

3 件

3 件

セッション $8:$ 工場経験

4 件

七ッション 9:クローズド化（その1)

3 件

セッション 10：クローズド化（その2）

3 件

蒸解条件が漂白性に及はす影響，酸素脱りグニン， ECF 漂白，クローズド化などが主要なテーマであっ た。工場経験のセッションでは, フィンランドの UPM -Kymmene 社 Wisaforest 工場, カナタの Domtar 社 Eddy 工場, フララジルの VCP 社 Luis Antonio 工場と Jacareí 工場から中濃度オソン ECF 漂白の発表があ り，排水負荷を大幅に減少できると共に，唒し薬品費 も節減できることが示され，多くの聴采の関心を集め ていた。NPE (non process element)によるスケー ル問題など、まだ研究を続けて解決していかなければ ならない課題はあるが, オゾンは漂白薬品としての地 位を確立しつつある。

尚，本報告では誌面の都合上全ての発表を紹介する ことはできないので，口頭発表の中から筆者が関心を 持った発表を幾つか紹介させて戴きたい。

\section{2. 技術・研究発表の概要紹介}

Session 1, Pulping

アルカリパルプの化学的性質と漂白性に関する蒸解パ ラメータの効果

THE EFFECT OF COOKING PARAMETERS ON THE CHEMICAL PROPERTIES AND BLEACHABILITY OF ALKALINE PULPS, (p. 37)

Goran Gellerstedt and Waleed Wafa Al-Dajani, Department of Pulp and Paper Chemistry and Technology. Royal Institute of Technology. KTH. Stockholm, Sweden

クラフト蒸解の加熱工程で急速にヘキセンウロン酸 が生成される事実に基づいてクラフト蒸解中のへキセ ンウロン酸の溶解・分解速度に関するモデルが開発さ れている。このモデルからへキセンウロン酸の溶解・ 分解速度が, 水酸イオン搌度の上昇, イオン強度と蒸 解温度の上昇と共に増加することが示されている。本 研究で，ポリサルファイドを直接蒸解液に添加する実 験を行ったが，通常のクラフトパルブに比べて収率が 高いという点以外に差は認められなかった。次に木材 チップをポリサルファイドで前处理してから蒸解し， ヘキセンウロン酸含有量に対する前処理奻果を調べた。 カッパー価に占めるへキセンウロン酸の量が 3-5\% と，通常のクラフトパルプの $13 \%$ よりも大幅に減少
していた。ポリサルファイドでチップの前処理を行う と収率が増加しており，直接ポりサルファイドを蒸解 液に添加するよりも，ヘキセンウロン酸の分解の点で より効果的であった。このポリサルファイドの働きは, ポリサッカライドの末端基の酸化による安定化とリク ニン構造の酸化によるリグニンのパルピンク薬品に対 する活性化によるものと考えられている。

Session 2, Pulping and washing

修正蒸解法のパルプ歩留まり向上分は漂白工程でどれ だけ保持されるのか？

HOW MUCH OF THE YIELD INCREASE FROM MODIFIED PULPING PROCESSES IS RETAINED DURING BLEACHING ? (p. 59)

Zhi-Hua Jiang, Barbara van Lierop, Aline Nolin, and Richard Berry, Pulp and Paper Research Institute of Canada, Pointe-Claire, QC. Canada

針葉樹材ブラックスプルース BKP の歩留まりを重 量法で測定した。ポリサルファイド (PS) とアント ラキノン $(\mathrm{AQ})$ による蒸解歩留まりの增加分は, 酸 素脱リグニン工程と漂白工程で保持されるだけでなく, 晒し減りが少ないのでコンベンショナル蒸解との差は むしろ拡大した。その理由は針葉樹材の蒸解歩留まり 向上はクルコマンナンの増加によるもので, キシラン の増加は少ないからであった。漂白工程ではキシラン を保護しているへキセンウロン酸が溶出してキシラン が溶出するので，未晒しパルプ中のキシランの少ない PS-AQパルプの方が漂白での歩隇りは小さくなった。 Session 3, Oxygen delignification 1

拡張酸素脱りグニン一前処理の効果と工程条件 EXTENDED OXYGEN DELIGNIFICATION-THE EFFECT OF PRETREATMENTS AND PROCESS CONDITIONS, (p. 89)

Birger Sjögren and Jan Höök, STFI, Stockholm. Sweden

酸素脱リグニンの選択性（あるカッパー価でのパル プ粘度）を改良するため, 前処理と薬品添加の評価を 行った。カッパー価を下げるために，酸素圧力を 1.5 $\mathrm{Mpa}$ ，温度を $115^{\circ} \mathrm{C}$ まで上げた。熱酸性処理と DTPA による前処理は，一段酸素段にDTPA, $\mathrm{Mg}^{2+}, \mathrm{H}_{2} \mathrm{O}_{2}$ を添加する場合とほほ同等の効果を示した。酸素脱り グニン後のパルプ粘度は, 同一カッパー価で比較する と, (1)過酸化水素添加の強化, (2DTPAの前処理, (3) $\mathrm{Mg}^{2+}$ 添加（過酸化水素漂白の場合）などにより上 昇していた。酸素圧力を高めると脱リグニン速度が加 速されたが，粘度に及ほす影䱥はほとんどなかった。 酸素脱リタニンを二段に分割すると，粘度が 10〜20 
$\mathrm{mL} / \mathrm{g}$ 改善された。さらに, 中間洗浄を行うと, 脱り グニン度が $65 \%$ の場合, 粘度が $50 \sim 70 \mathrm{~mL} / \mathrm{g}$ 上昇し た。選択性は，DTPA 処理を行った後に過酸化水素 を強化した酸素段が最大となり,脱リグニン度が $65 \%$ の場合，粘度は約 $940 \mathrm{~mL} / \mathrm{g}$ であった。中間洗净を導 入した二段酸素脱リグニンと比較すると, 脱リグニン 度 $65 \%$ におけるパルプ粘度は $40 〜 50 \mathrm{~mL} / \mathrm{g}$ 上昇した。 Session 4, Oxygen delignification 2

酸素脱りグニンの限界を拡張

EXTENDING THE LIMITS OF OXYGEN DELIGNIFICATION, (p. 123)

F. S. Chakar, L. Lucia and A. J. Ragauskas, Institute of Paper Science and Technology. Atlanta, GA , USA

低リクニン含有量（カッパー価 26.6）と高リグニ ン含有量（カッパー価 56.2）の NKP の漂白性を, 通 常の酸素, 拡張二段酸素 $\mathrm{OO},(\mathrm{E}+\mathrm{O}) \mathrm{D}_{\mathrm{kf}: 0.05}(\mathrm{E}+\mathrm{O})$ により評価を行った。高カッパー価パルプの漂白性は， 低カッパー価パルプより優れていた。同一アルカリ添 加量では，どちらのパルプに関しても脱リグニン度は $\mathrm{OO}>\mathrm{O}>(\mathrm{E}+\mathrm{O}) \mathrm{D}_{\mathrm{kf:0.05}}(\mathrm{E}+\mathrm{O})$ の順であった。後半 のシーケンスを温和な条件にしたところ，粘度の高い パルプが得られた。へキセンウロン酸は, 低カッパー 価パルプの場合, カッパー価の $22 \%$ に寄与していた が, 高カッパー価パルプにはほとんど奇与していなか った。高カッパー価パルブと低カッパー価パルプの漂 白性の変化に関しては，更にパルプと漂白排水中に含 まれる残りグニンの分離，同定を行い検討した。 ${ }^{13} \mathrm{C}-$ NMR によるパルプの残リクニン分析の結果, 高カッ パー価パルプは, 低カッパー価パルプと比較して, $\beta$ ーーーアリールエーテル, メトキシル基の存在が多く認 められた。また，高カッパー価パルプのリクニン骨格 には，樎合芳香族化合物とジフェニルメタン官能基の 存在が少ないことがわかったここれらの結果は, 縮合 フェノール性化合物が末唒しパルプの酸素脱リグニン での漂白性に影響を及ほすという仮説を支持するもの であった。漂白排水中のリクニンの分析結果は，反応 条件の変化によってパルプの漂白性が異なることを支 持していた。パルプの漂白性の違いは，高カッパー価 パルプと低カッパー価パルプに存在するリクニン及び ヘキセンウロン酸の構造の違いに起因していた。

Session 5, ECF bleaching.

ECF 漂白における二酸化塩素脱リグニンの改良 IMPROVEMENT OF ClO 2 DELIGNIFICATION IN ECF BLEACHING, (p.159)

Dominique Lachenal and Christine Chirat, Ecole Française de Papeterie. Saint Martin d'Hères, France
二酸化塩素漂白では添加量の $50 \%$ しか漂白に有効 に利用されておらず，残りの $50 \%$ はリグニンの反応 生成物と反応していると推定された。D段の後で洗浄 してもリグニン反応生成物は除去できなかったが，D 段の後でアルカリ処理してから洗浄を行う（DE）(DE)-(DE) シーケンスがリダニン反応生成物を有効 に除去でき，晒し薬品を節隇できることを見出した。 クラフトパルプの漂白性についての新しい考察

A NEW INSIGHT INTO THE BLEACHABILITY OF KRAFT PULPS, (p. 163)

Zhi-Hua Jiang. Barbara van Lierop, Aline Nolin, and Richard Berry, Pulp and Paper Research Institute of Canada, Pointe-Claire, QC, Canada

$\mathrm{PS}-\mathrm{AQ}$ 蒸解パルプを通常の蒸解法のパルプと同 じカッパー価で比較すると， $\mathrm{D}_{0} \mathrm{EoDED}$, 或いは $\mathrm{OD}_{0}$ EoDED シーケンスでの漂白性が悪かった。また，酸 素脱リグニンしたパルブは，末唒しパルプと同じカッ パー価で比較して，DoEo シーケンスでの漂白性が要 かった。 $\mathrm{AQ}$ と酸素はラジカルを発生し、ラジカルに よりへキセンウロン酸とリグニンとが共有結合し，そ のため漂白性が悪化していると推定された。

Session 7, Pulp quality

クラフトパルプ表面のリグニンの由来

THE ORIGINS OF KRAFT PULP FIBRE SUR FACE LIGNIN，(p. 197)

Kecheng Li and Douglas W. Reeve, Department of Chemical Engineering and Applied Chemistry, and Pulp \& Paper Centre, University of Toronto, Toronto. Canada

ミドルラメラのリグニンは，CTMP 紴維やクラフ 卜蒸解初期の樴維の表面に存在するリグニンに占める 割合が大きかったか，クラフト蒸解終了後の驖維の表 面に存在するリクニンに占める割合は小さかった。ミ ドルラメラのリクニンは蒸解で殆ど溶出し，溶出した リグニンが䄉維表面へ再吸着して, 䄉維表面に高いリ タニン溇度を形成していると考えられた。

クローズドシステムとオープンシステムにおける TCF 漂白

TCF BLEACHING IN CLOSED AND OPEN SYSTEMS (p. 207)

Agneta Fuhrmann, Rauni Rautonen, Leena Toikkanen and Pirkko Liias, KCL, Finland

漂白ブラントがクローズド化されていくとリグニン， 炭化水素, 有機酸などの溶存物質の溇度が上昇する。 循環する金属イオン渡度の上昇も有害で，沈殿物を生 成したりラジカル反応を引き起こす。そこで，クロー 
スド化が進んでいる工場の漂白パルプとクリーンなラ ボで漂白したパルプを比較した。用水使用量が $10 \mathrm{~m}^{3}$ /BDt とクローズド化が進んでいる Metsa Rauma 工 場は $\mathrm{OOZP}_{1} \mathrm{QP}_{2}$ の漂白シーケンスでNBKPの TCF パルプを生産している。工場のパルプをラボで良く洗 浄してから漂白し, 工場で漂白したパルプと此較した ところ，Z段でカルシウム，マンガンなどの金属イオ

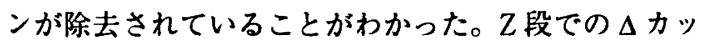

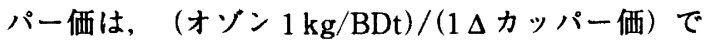
工場とラボで同じであった。工場のパルプは， $\mathrm{P}$, の 漂白性だけが悪かった。工場では徆し白水が循環して いるので過酸化水素が余分に消費されていると推定さ れた。その他の漂白段の漂白性は工場とラボとで同じ であった。パルプの粘度、強度は殆ど等しかった。顕 微鏡と精䥞な表面分析法で工場のパルブ樴維表面を観 察したが沈殿物はなかった。

Session 8, Mill experiences

高カッパー価蒸解，拡大酸素脱リグニン，Z/D漂白 を組み合わせた低コストで高品質の針葉樹材パルプの 製造

LOW COST AND HIGH QUALITY SOFTWOOD PULP PRODUCTION BY COMBINING HIGH COOKING KAPPA, EXTENDED OXYGEN DELIGNIFICATION AND Z/D BLEACHING, (p. 217)

Marko Siltala, Kenneth Winberg and Niklas Keskinen, UPM-Kymmene, Wisaforest Pulp Mill, Pietarsaari, Finland,

フィンランドの Wisaforest 工場\# 2 系の NBKP 生 産ラインでは，D-ECF とZ-ECFを生産している。D -ECF は O/O-D-Eop-D-Pであり，Z-ECF は O/OZ/D-OP-D-P の漂白シーケンスである。Z-ECFは\# 1 系 (LBKP) のオソン発生機の余力を活用している。 酸素段後カッパー価を 25 から 18 に下げ，オソンと過 酸化水素を使用して二酸化塩素使用量を最小にするこ とによって，唒し菜品費が $16 \%$ 節減された。排水の COD は $27 \%$, AOX は $71 \%$ 滅少した。

\section{オゾン ECF 漂白の操業経験}

OPERATING EXPERIENCE WITH AN OZONEBASED ECF BLEACHING SEQUENE, (p. 225)

E Fred Munro and John Griffiths, Domtar Inc., Eddy Specialty Papers Division, Espanola, ON. Canada

カナタの E. B. Eddy 工場は, 1999 年 5 月に LBKP に中湿度オソン漂白設備を設置した。漂白シーケンス は $\mathrm{ZD}_{\mathrm{n}}-\mathrm{E}-\mathrm{D}_{1} \mathrm{n}-\mathrm{D}_{2}$ である。オソンは 4 6 kg/ADt 添 加している。ムカッパー価はオソン添加率が $1 \mathrm{~kg} / \mathrm{ADt}$ の時は 1.0 で, $6 \mathrm{~kg} / \mathrm{ADt}$ の時は 0.7 であった。D-ECF
と Z-ECFではパルプ強度と粘度に差がなかった。DECF では，バーチはアスペンよりも漂白しにくいが, オゾンでは両者の差が少なくなり，オゾンによる二酸 化塩素の置換率は, アスペンが 2.1 , パーチが 3.8 で あった。これらは, 理論值の 1.7 よも高く, オソン 漂白の効率は良かった。オゾン漂白導入により排水負 荷とピッチが減少した。

\section{VCP 社の漂白工場の改良}

IMPROVEMENTS IN THE BLEACH PLANTSVCP CASE, (p. 231)

Marcelo Rodrigues, Marco A.L. Peixoto, Altair Zolio and Eduardo C. Tonelli, VCP-Jacareí Mill, -SP-Brazil, (pp. 231)

VCP 社は南米で最大の工業コングロマリットVotorantim クループ傘下にある。VCP 社は $2 つ の$ 紙パ ルプ一貫工場（非塗工紙と塗工紙）を所有している。 両工場はサンパウロ州の Luis Antonio 市と Jacarei 市 にあり，中浱度オゾン漂白を導入してLBKPを生産 している。Luis Antonio 工場は O (Op) (DZ) EopD でスタートしたが，DのキャリーオーバーによってZ のミキサーが腐食し損伤してしまった。そこで 1 年後 にDとZの順番を逆にして O (Op) (ZD) EopDに変 更してから順調に操業を続けている。Jacarei 工場の ECF は， OQOpZ (DnD) でスタートしたが，二酸化 塩素使用量が $30 \mathrm{~kg} / \mathrm{ADt}$ と多かったため, OOZD (PO) に変更し， $16 \mathrm{~kg} / \mathrm{ADt}$ に減らすことができた。 Z-ECF パルフの引っ張り強度はスタンタードパルプ よりも上昇した。アルカリ性排水の性状は著しく改善 された。

Session 9, System closure 1

効率的な資本支出による ECF 漂白排水処理の改良 SIGNIFICANT IMPROVEMENTS IN ECF BLEACHING USING A MINIMAL CAPITAL APPROACH TO BETTER FILTRATE MGMT, (p. 249)

Arvind Thakore. Jim Oei and Stan Heimburger, Western Pulp Inc., Squamish, B. C. Canada

Western Pulp Squamish 工場では市販 LBKPを製 造し, 漂白に $[\mathrm{D}(\mathrm{EO})](\mathrm{EOP}) \mathrm{D}$ を導入している。 漂白設備は 6 台のデフューザーウオッシャー付きの置 換漂白で, 向流洗浄で酸性排水がアルカリ漂白段にか かっていた。そこで，なるべく $\mathrm{pH}$ ショックがないよ うに，同じ $\mathrm{pH}$ の排水でパルプを洗浄するように変更 したところ,スケールが隇少し, 漂白薬品費を 7〜9\% 削減することができた。完成パルプ白色度の上䒜, TOX 含有量の減少も認められた。 
濃縮・沈殿工程の組み合わせによる中性及び酸性漂白 排水からの NPE 除去

REMOVAL OF NPE'S FROM NEUTRAL AND ACIDIC BLEACH FILTRATES BY COMBINING EVAPORATION AND PRECIPITATION, (p. 253)

Anu Seisto, Per Tomani, Risto Järvinen and $\AA$ ke Rasmuson, STFI. Stockholm, Sweden

漂白排水には，木材から工程内に持ち込まれる金属 イオン（ $\mathrm{Al}, \mathrm{Si}, \mathrm{P}, \mathrm{Ca}, \mathrm{Ba})$ が含まれており，これ らは NPE (non-process element) と呼ばれている。 漂白排水のクローズド化を図る際には，スケール発生 を考慮に入れた NPE 処理が必要となる。本研究では, $\mathrm{TCF}, \mathrm{ECF}$ 漂白工程の Q 段, D 段排水中に含まれる NPE 除去について検討を行った。処理工程には，濃 縮, 沈殿, 分離の操作があるが, NPE 除去には, 湄 縮後に沈殿処理を行った方がより効果的であることを 見出した。Q段排水については, pH 6 で浱縮を行う と NPEが沈段して十分な効果があがったが， $\mathrm{pH}$ 10 まで上げることにより更なる除去が可能であった。 D 段排水の NPE を効果的に除去するためには, 涶樎 後に沈殿操作を行うか, 滤液を $\mathrm{pH} 10$ 以上の高 $\mathrm{pH}$ で 濃縮する操作が必要であった。

Session 10, System closure 2

パルプ䇣蜀液中で、“フリーで”錯体を形成している 金属イオンと沈殿した金属イオンの分眼のドンナン平 衡を用いたモデル化

MODELLING THE DISTRIBUTION OF “FREE”, COMPLEXED AND PRECIPITATED METAL IONS IN A PULP SUSPENSION USING DONNAN EQUILIBRIA, (p. 273)

Christin Sjölander, Jan Lidén and Lars-Olof Öhman. Modo Paper R \& D, Örnsköldsvik Sweden.

O段，P段のパルブに関して，金属含有量と䄉維の 電荷の分析を行い, $\mathrm{Q}$ 段処理中の挙動をシミュレート するためにO段のパルブを調製した。二価の金属イ
オンは炭酸塩として存在していることが同定され, 酸 素脱リグニンを行った瀻維のアニオン電荷は, $\mathrm{Na}^{+}$イ オンにより中和されていることがわかった。酸を添加 した場合にこれらの炭酸塩は徐々に溶解し，二価の金 属イオンが放出され，䄉維壁中の $\mathrm{Na}^{+}$イオンと置き換 わった。カチオン量が䄉維のイオン交換能力を上回る と，かなりの量の金属イオンがサスペンション中に放 出された。強力なキレート堉を添加した場合, 二価の $\mathrm{Mn}^{2+}$ はアニオン性の錯体を形成し, 樴維壁から放出 されることが確認された。P 段処理のように,パルフ が再びアルカリ性になると, $\mathrm{Mg}^{2+}$ と少量の $\mathrm{Ca}^{2+}$ が再 沈殿した。沈殿若しくは錯体化している金属イオンの 形態が明らかな場合, 金属イオンの分布は Donnan 理 論を用いて定量的にモデル化することができた。

3. おわりに

会議の前の週には, トロント大学を訪問し, Reeve 教授と ECF 漂白について意見を交換した。トロント 大学は Rapson 教授の時代に二酸化塩素漂白を工業化 したことで有名であり, Reeve 教授が後を継いでから も，自ら会社を作って二酸化塩素漂白を積極的に展開 している。またトロント近郊の E. B. Eddy 工場を訲 問し, 最新の中濃度オゾン漂白設備について操業担当 者から詳しい話を聞くことができた。日本製紙は全工 場を ECF 化するため, 二酸化塩素 ECF 漂白とオソ ン ECF 漂白の導入を進めており，勇払工場では 2001 年 1 月の稼動を目指して日本で最初の中濃度オゾン漂 白設備を建設中である。インターネットの普及により

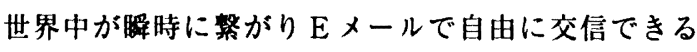
ようになったとは言え，重要な情報は人と人との出会 いで得られ，その出会いから新たな知恵が生まれる。 今回の海外出張で知り合った人達とのネットワークを 大切にし, 今後の研究に生かしていきたいと考えてい る。次回の国際パルプ漂白会議は 2002 年 5 月に米国 オレコン州ポートランドで開催される予定である。 


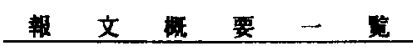

\section{0 年 TAPPI 国際環境会議報告}

紙パルプ技術協会 田口徹

コロラド州の州都デンバー市のコロラドコンベンションセンターで，5月 8 日から 10 日まで「21 世 紀に向けてこれからの㻴境問題に道筋を付けよう」というテーマの下で開催された。今年は従来と違っ て，初日の午後は NCASI 主催の全参加者対象の公開セッションに当てられた。

会議に報告された内容を見ると，生物処理に関する関心が年々高まっているようで，排水処理のみな らずクラスタールールの大気対策としての MACT がらみで, KP のコンデンセートの処理にも微生物 を使っていこうとする傾向が窺われる。又, 初めてバイオサイドのセッションも設けられた。

その他, EPAからは Partners for the Environment というバンフレットが会場に置かれていたが, 内容は民間企業に EPA と協力して骤境改善を図り，企業収益の向上を目指そうというもので，温暖化， 環境ラベル，省エネルギー，㻴境会計，化学薬品他 20 の web site を用意して積極的な協力を呼び掛け ていた。

米国内のエネルギー多消費型産業 9 業種の新技術開発を支援しているエネルギー省工業技術局からは, 紙パルブを含む林産物の今後の発展と国際競争力確保を目的にAF\&PA が作成した Agenda 2020 に呼 応して，現時点で進められている各種新技術を紹介する資料が多種類配布されていた。最終日に行われ た地球温暖化のパネルデイスカッションでは，ホワイトハウスの気候変動タスクホースの担当者が加わ っていた。

このようにTAPPI という一民間工莱団体の会議に，関連の国家機関が夫々に参画している状況を見 ると，米国では製絓産莱の国除競争力强化へ向けて，官民挙げて並々ならぬ決意で取組んでいることを 強く感じた。

(本文 47 ページ)

\section{0 年国際パルプ漂白会議に参加して}

\section{日本憋紙株式会社 技術研究所パルブ研究室 宮西 孝則}

2000 年 6 月 27 日から 30 日までの 4 日間にカナタのハリファックスで開櫵された国際パルブ漂白会 議（2000 International Pulp Bleaching Conference）に参加する機会を得たので概要を報告する。

研究発表は, 口頭発表が 10 のセッションで 34 件, ポスターが 13 のセッションで 40 件, 合計 73 件 の報告があった。

(本文 55 ページ)

\section{第 67 回紙パルプ研究発表会の概要}

\section{紙バルプ技術協会 木材科学委員会}

第 67 回紙パルフ研究発表会は, 平成 12 年（2000 年）6月 28 日（水） 29日（木）の 2 日間, 東京 王子の北とびあにおいて開催された。発表件数は, 産・官・学各界から, 口頭発表 29 件, ポスター発 表 8 件，合計 37 件であった。参加者は 347 名だった。発表内容の概要をまとめた。 